\title{
Institutionalization of State Support and Development of Sectoral Entrepreneurship of Rural Areas
}

\author{
Iryna V. Forkun \\ Khmelnytskyi National University \\ 29016, 11, Institutskaya Str., Khmelnytsky, Ukraine \\ Oleksandr S. Prystemskyi \\ Kherson State Agricultural University \\ 73006, 23 Sritenska Str., Kherson, Ukraine \\ Olha S. Chernenko \\ National Scientific Centre "Institute of Agrarian Economics" \\ 03127, 10 Heroes of Defense Str., Kyiv, Ukraine \\ Iryna A. Chkan \\ Dmytro Motornyi Tavria State Agrotechnological University \\ 72310, 18 B. Khmelnitsky Ave., Melitopol, Ukraine \\ Inna Ye. Yakusheva \\ Dmytro Motornyi Tavria State Agrotechnological University \\ 72310, 18 B. Khmelnitsky Ave., Melitopol, Ukraine \\ cross'refhttp://dx.doi.org/10.5755/j01.ppaa.20.3.28405
}

\begin{abstract}
The article presents the implementation of the results of supporting sectoral entrepreneurship in rural areas as a multifunctional and multi-channel process of formation, attraction, and use of financial resources provided by the rules of the institutional environment of state policy. A methodical approach to the integrated assessment of indicators of the target direction of the involved financial resources of the state and their impact on the development of sectoral entrepreneurship in rural areas is presented. It is proved that the specific criteria that determine the scenarios of consolidation of tax revenues to local rural budgets are minimization of discretion, compensation, and compromise, budget adequacy, complementarities, as well as the sequence of changes in parameters and flexibility of the tax system which allows responding quickly to changes in the institutional environment of state support of sectoral entrepreneurship. Indicators of state support for risk insurance of sectoral entrepreneurship, volumes of accumulated revenues of local budgets in decentralized rural areas of Ukraine are analyzed. A cognitive model is proposed. It determines the hypothetical ability of the multifactorial system of the institutional environment of state policy to influence the level of financial capacity of sectoral enterprises, taking into account the tax burden and targeted use of state financial resources for production, processing, and storage of agricultural products as well as to update the technological process.
\end{abstract}

Keywords: state support, sectoral entrepreneurship, local budgets, rural areas, financial capacity.

Raktažodžiai: valstybès parama, sektorinis verslumas, vietos biudžetai, kaimo vietovès, finansinis pajègumas 


\section{Introduction}

The development and effective functioning of sectoral entrepreneurship, which in the dynamic socio-economic space requires a reorientation of state financial support for the proper use of land and production resources, requires comprehensive changes in tax policy, a significant reorientation of markets - from domestic consumption and trade to new world markets. The active position of the state on building the institution of local self-government in terms of the formation and implementation of local budgets requires a balanced and effective policy in the field of financial activities and strengthening the competitiveness of sectoral entrepreneurship in rural areas. Since sectoral entrepreneurship in rural areas is a system-forming vector of national, food, financial, environmental, and energy security, it must be provided by state regulatory and stimulus levers in decentralized areas.

European Union (EU) and the United States (US) rural development policy has many common goals, but it differs slightly in the mechanisms and priorities for implementation, determining the role of agricultural production in rural development (Schmit and Severson, 2021). The main areas of measures to support rural development in the US are: (1) economic development of rural areas, stimulating the creation and development of business; (2) infrastructure development; (3) fight against poverty (Deller and Whitacre, 2019). The main difference between US policy and the EU is that the directions of development of sectoral entrepreneurship in rural areas are fixed within the framework of the Common Agrarian Policy, an integral part of which is sustainable development. While the US also focuses on critical areas, they are not legally identified as rural development programs (Graskemper et al., 2021; Cullen et al., 2020).

Issues of formation of the state policy of sustainable development and financial support of entities of sectors of the national economy were investigated by such scientists as O. Budai (2015), D. Chernikov (2013), O. Kyrylenko and O. Tulai (2017). The issue of the global influence of world financial institutions, fierce domestic and international competition, which deepens the understanding of the dependence of sectoral entrepreneurship in the context of decentralization of rural areas and outlines the regulatory financial levers of state policy on channels of redistribution at the local level to support financial self-sufficiency of regions, was investigated by - M. Malik (2012), O. Oliinyk (2013), V. Zhuk (2011).

Based on the topic of the research, a hypothesis was formed: the formation of safe conditions for the development of rural areas requires the use of a balanced systemic approach and decisionmaking at all hierarchical levels of management of the national economy.

\section{Methods}

We propose a comprehensive methodological approach to assessing the impact of state policy on the development of sectoral entrepreneurship in rural areas, which is carried out through financial, economic, budgetary, and social indicators of the target direction of the involved financial resources. Stages of assessing the impact of state policy on the development of sectoral entrepreneurship: 1) selection of indicators of development of sectoral entrepreneurship with their division into financial and socio-economic ones; determining the dominants of providing state financial support to business entities; 2) calculation of a generalizing indicator that determines the degree of influence of state policy on the financial and socio-economic development of sectoral entrepreneurship in rural areas, taking into account the directions of stimulating and disincentive factors; 3 ) calculation of a complex (generalized) integrated indicator of the impact of state policy on the financial and socio-economic development of sectoral entrepreneurship in rural areas.

The selection of financial, economic, budgetary, and social indicators and the target direction of financial resources for rural development, as well as diagnostics of the state of production management, processing, and storage of agricultural products, is formed through information space systems and involves building a matrix of source data $X=x_{i j}$, where $x_{i j}$ is is the value of the $\mathrm{j}$-th indicator for the i-th object. As indicators can have different natures and incomparable values, data 
standardization is carried out. To do this, it is necessary to change the matrix $X$ to the matrix $W$. The elements of the matrix $W$ are calculated by the (Eq. 1).

$$
W=\frac{x_{i j}-\bar{x}_{j}}{\sigma_{j}}
$$

where, $\bar{x}_{j}$ is is the average value of the $\mathrm{j}$-th indicator; $\sigma_{j}$ is standard deviation of the $\mathrm{j}$-th indicator.

Accordingly, these parameters are calculated by (Eqs. 2-3) (Law of Ukraine No. 1877-IV, 2004).

$$
\bar{x}_{j}=\frac{1}{m} \sum_{j=1}^{n} x_{i j},
$$

where, $m$ is the number of output indicators used to obtain a comprehensive indicator; $n$ is time period of calculation.

$$
\sigma_{j}=\sqrt{\frac{1}{m} \sum_{j=1}^{n}\left(x_{i j}-\bar{x}_{j}\right)^{2}},
$$

The next step in this algorithm is to differentiate the features of the observation matrix. All changes are divided into stimulants and destimulants. The basis for the division of features into two groups is the nature of the impact of each of them on the level of the indicator of the quality of attracting financial resources that provide targeted funding for sectoral entrepreneurship in rural areas. The division of features into stimulators and destimulators provides a basis for the formation of a reference point $R_{0}$ with coordinates $W_{01} \ldots, W_{02} \ldots, W_{0 n}$, which is recognized by (Eqs. 4-5).

$$
\begin{gathered}
W_{0 j}=\max W_{i j}, j \in J, \\
W_{0 j}=\max W_{i j}, j \notin J,
\end{gathered}
$$

where $J$ is indicators-stimulators; $W_{i j}$ is standardized value of the $\mathrm{j}$-th indicator for the $\mathrm{i}$-th period.

The distance between the individual points-units and the point, which represents the reference point, is denoted as $S_{i 0}$ and calculated by (Eq. 6) (Oliinyk, 2013).

$$
S_{i 0}=\sqrt{\sum_{j=1}^{n}\left(w_{i j}-w_{0 j}\right)^{2}},
$$

The closer the value of the indicator $f_{i}$ to one, the higher the level of evaluation of the indicator. Figure 1 presents a methodological approach to the integrated assessment of indicators of the target direction of the involved financial resources of the state and their impact on the development of sectoral entrepreneurship in rural areas. This allows determining changes in the level of financial capacity of businesses, subject to the use of government support (Eq. 7) (Trusova et al., 2018).

$$
\operatorname{FCSIE}_{i}=\frac{1}{\sum_{i}\left(1-K_{i}\right)^{2}},
$$

where, $F C S I E_{i}$ is indicator of the state of financial capacity of the entities of sectoral entrepreneurship of rural areas of the $\mathrm{i}$-th period; $K_{i}$ is the $\mathrm{i}$-th coefficient of financial capacity of the 
entities of sectoral entrepreneurship of rural areas in relation to its maximum (normative, optimal) level.

The optimal level is the maximum (regulatory, optimal) value for the entire analysis period.

\begin{tabular}{|c|c|c|c|}
\hline Step I & \multicolumn{3}{|c|}{$\begin{array}{l}\text { Integral assessment of indicators of the target direction of the involved financial resources of the } \\
\text { state and their influence on financial and economic and budgetary and social development of } \\
\text { sectoral entrepreneurship of rural areas }\end{array}$} \\
\hline \multicolumn{4}{|c|}{$\begin{array}{l}\qquad f_{i}=1-\frac{S_{i 0}}{S_{0}}, S_{0}=\bar{S}_{0}+2 \times Q_{0}, \bar{S}_{0}=\frac{1}{m} \sum_{i=1}^{m} S_{i 0}, Q_{0}=\sqrt{\frac{1}{m} \sum_{i=1}^{m}\left(S_{i 0}-\bar{S}_{0}\right)^{2}} \\
\text { where, } f_{i}-\text { the value of the integrated indicator; } S_{i 0}-\text { the distance between the individual points-units and } \\
\text { the point } S_{0} \text {, which represents the reference point; } m \text { - the number of output indicators for calculating the } \\
\text { complex indicator; } Q_{0} \text { - integrated indicator. }\end{array}$} \\
\hline Step II & \multicolumn{3}{|c|}{ Formation of a "reference point". Calculation of Euclidean distance } \\
\hline Step III & \multicolumn{3}{|c|}{$\begin{array}{l}\text { Scaling of the integrated indicator of the target direction of the involved financial resources of the } \\
\text { state and their influence on financial and economic and budgetary and social development of } \\
\text { sectoral entrepreneurship of rural areas }\end{array}$} \\
\hline & $\frac{\mathrm{q}}{\text { The distance of com }}$ & $\begin{array}{l}\text { egrated indicator } \mathrm{v} \\
\text { nancial resources }\end{array}$ & evel of the involved \\
\hline & $\begin{array}{c}\text { low } \\
\text { from } 0 \text { to } 0.33\end{array}$ & $\begin{array}{l}\text { medium } \\
\text { from } 0.34 \text { to } 0.66\end{array}$ & $\begin{array}{l}\text { high } \\
\text { from } 0.67 \text { to } 1.0\end{array}$ \\
\hline
\end{tabular}

Figure 1. The sequence of integrated assessment of indicators of the target direction of the involved financial resources of the state and their impact on the development of sectoral entrepreneurship in rural areas

Source: Authors.

The coefficient of the level of ensuring the financial capacity of sectoral entrepreneurs of rural areas is determined by (Eq. 8) (Trusova et al., 2018):

$$
K_{i}=\sum_{n} \frac{F v_{i}}{M(N, O)_{i}}
$$

where, $F_{v i}$ is the actual level of the i-th coefficient; $M(N, O)_{i}$ is the maximum (optimal, normative) level of the $\mathrm{i}$-th coefficient among those achieved during the analysis period; $n$ is the number of coefficients.

Thus, Eq. 7 will look like this (Trusova et al., 2018) (Eq. 9):

$$
F C S I E_{i}=1 \div\left[\begin{array}{l}
\left(1-\frac{P a_{f}}{P a_{p}}\right)^{2}+\left(1-\frac{P s n_{f}}{P s n_{p}}\right)^{2}+\left(1-\frac{K s_{f}}{K s_{p}}\right)^{2}+\left(1-\frac{K p s o p_{f}}{K p s o_{n}}\right)+ \\
+\left(1-\frac{K r c_{f}}{K r r c_{n}}\right)^{2}+\left(1-\frac{K t l_{f}}{K_{t l_{p}}}\right)^{2}+\left(1-\frac{K a_{f}}{K a_{n}}\right)^{2}+\left(1-\frac{K s i f_{f}}{K s / f_{n}}\right)^{2}+ \\
+\left(1-\frac{K s_{f}}{K f_{n}}\right)^{2}
\end{array}\right]
$$

where, $P a_{f}, P a_{p}$ is the actual and maximum value of return on assets; $P s n_{f}, P s n_{p}$ is the actual and maximum value of the profitability of sold products on the net profit of the subject of sectoral entrepreneurship in rural areas; $K s_{f}, K s_{n}$ is the actual and normative level of solvency; $K p s \operatorname{sp}_{f}, K p s \operatorname{sp}_{n}$ is the actual and normative level of providing stocks with own funds; $K r r c_{f}, K r r c_{n}$ is the actual and maximum level of working capital turnover; $K t l_{f}, K t l_{n}$ is the actual and regulatory level of total 
liquidity; $K a_{f}, K a_{n}$ is the actual and regulatory level of the ratio of receivables and payables; $K s / f_{f}$, $K s / f_{n}$ is the actual and normative value of the level of self-financing; $K f s / f f, K f s / f_{n}$ is the actual and regulatory value of the level of financial stability.

We have proposed criteria for rational state support of sectoral entrepreneurship in rural areas $(K s s)$ at the level of three main subsystems, which have certain components and elements: financial (taking into account banking and insurance subsystems), budgetary, social, and economic (taking into account monetary and investment subsystems), (Eq. 10) (Trusova et al., 2018):

$$
K_{S S}=f \sum(B P, I P, B S P, P P, \operatorname{In} P),
$$

where, Kss is criterion of the rationality of the state support of entities of sectoral entrepreneurship of rural areas, USD; $B P$ is budget costs of the banking subsystem, USD; $I P$ is budget costs of the insurance subsystem, USD; $B S P$ is cost of the budget and social subsystem, USD; $P P$ is budget expenditures of the monetary subsystem, USD; In $P$ is budget expenditures of the investment subsystem, USD.

The calculation of the reference point for each component of the subsystem and the integrated indicator of the subsystem is carried out according to the (Eq. 11) (Trusova et al., 2018):

$$
I_{j}=\sum a_{i j} * x_{i j}
$$

where $I_{j}$ is the integrated indicator of state support for sectoral entrepreneurship in rural areas; $a_{i j}$ is weighting factors that determine the degree of contribution of the $\mathrm{i}$-th indicator to the integrated index; $x_{i j}$ is the initial indicator.

After selecting the reference point among the components of the subsystems of state support, the next step calculates the integrated index (Eq. 12) (Trusova et al., 2018):

$$
I=\sum b_{j} * I_{j}
$$

where $b_{j}$ is weight coefficients (point of reference) of the constituent subsystems of state support of sectoral entrepreneurship entities.

The use of these indicators allows making informed management decisions on the redistribution of the structure of tax revenues from sectoral entrepreneurship entities at the regional and local levels, thus ensuring the socio-economic development of rural areas, taking into account the institutional environment of state policy. Higher-level institutional assistance may be needed to finance local capital construction projects. At the same time, the specific criteria that determine the scenarios of consolidation of tax revenues to local budgets are minimization of discretion, compensation, and compromise, budget adequacy, complementarities, as well as the sequence of changes in parameters and flexibility of the tax system, which allows responding quickly to changes in the institutional environment of state support for sectoral entrepreneurship.

\section{Results and Discussion}

The national system of state support for sectoral entrepreneurship with an emphasis on the decentralized vector of rural development identifies its priority areas: main activity; investment activity - reproduction of resource potential of sectoral entrepreneurship entities that will provide their competitiveness; innovative development - selection in crop production and animal husbandry, training, the introduction of modern technologies, etc. Moreover, as a set of tools for state regulation of sectoral entrepreneurship, it is developing in three main forms: (1) direct form: financial support, by reducing the cost of loans; financial support of entrepreneurial activity in agriculture; financial support for the development of farms and the provision of loans; state support of the livestock industry; (2) indirect form: state procurement; foreign economic regulation of agro-industrial complex activity (quotas); financial support for cheaper financial leasing for the purchase of 
machinery and equipment; (3) conditionally direct form: special tax regimes; rent for special water use, zero VAT rate (Law of Ukraine No. 1877-IV, 2004; Oliinyk, 2013).

The draft Concept of Rural Development until 2030 provides for the provision of sustainable rural development, which provides for the unity and balance of its three components: economic, social, and environmental (Trusova et al., 2019): the economic component is based on increasing the production of competitive agricultural products, business development and small farms in rural areas (Ministry of Economic Development, Ministry of Economic Development, Trade and Agriculture of Ukraine); social is based on creating optimal social conditions and improving the quality of human life as the main value of society, providing employment and improving the living standards of the rural population (State Employment Service and the Antimonopoly Committee of Ukraine); ecological is based on the rational use of natural resource potential of rural areas and their environmental safety (Ministry of Agrarian Policy and Food of Ukraine). Rural development policies will take into account local needs and stimulate local initiatives. This will create new jobs in the nonagricultural sector, in the development of various forms of entrepreneurship in rural areas, the production of more high value-added products and organic products, and improved infrastructure, which will improve the quality of life in rural areas.

Calculations of indicators of financial and economic, budget, and social development of rural areas under the condition of targeting the financial resources of the state for the development of sectoral entrepreneurship showed that for the period 2010-2019, there is an average level of diversification of the economy of united territorial communities (OTG). Thus, among the economic indicators of the impact of state policy on the target direction of attracted financial resources in rural areas, the most important are the amounts of funding for OTG activities from various sources of their formation. The main disincentive factor that negatively affected the value of the economic indicator is the decrease in the level of profitability of operating activities of entrepreneurship entities, which in 2019 decreased compared to 2010 to $11.7 \%$ against $22.8 \%$. Also, during this period, there was a decrease in export operations in 2019 to 1.71 billion USD against 14.1 billion USD in 2014. The average value of the generalized financial indicator of the impact of state policy on the target direction of the attracted financial resources in rural areas for the period 2015-2019 was 0.88. The high level of this indicator is due to changes in the tax burden (due to the abolition of the special VAT regime ( $80 \%$ from the number of VAT liabilities paid to the state budget). Due to the special VAT regime, the targeted use of accumulated financial resources was directed to the working capital of production, processing, and storage of agricultural products, thus increasing the net profit of entrepreneurship entities. The largest share of the financial indicator is formed by the size of credit and forward transactions, financial leasing transactions, investments, insurance, and government support. Their value in the structure of the generalizing indicator has a reference point -0.74 with the value of the coefficient 0.88 (Budai, 2015; Kyrylenko, O. and Tulai, O., 2017; Trusova et al., 2019).

However, with the reduction of the tax burden on the entities of sectoral entrepreneurship, there was an increase in the number of social burdens in the form of payment of rent for land plots (shares). At the same time, the generalizing budgetary and social indicator of the influence of state policy on the target direction of financial resources of rural areas has a Euclidean distance of 0.86. The annual increase in the rent for land is due to the inflation index, which is regulated by the implementation of state institutions, as well as market relations, as the number of remuneration for agricultural land has a rigid position of the state (Law of Ukraine No. 2629-VIII, 2018). The decrease in the general indicator of the impact of state policy on the financial, economic, budgetary and social development of rural areas to the average level is 0.67 , due to the unstable state of the financial market in the country, which is significantly affected by the political crisis, devaluation of the national currency, increase in value of lending resources in banking institutions, increase in insurance payments, increase in credit and discount rates of the NBU. The disincentive criteria for influencing the indicator are an increase in the number of insurance premiums and bank lending rates in 2010, as well as a reduction in government support since 2014. Accordingly, this trend has led to a decrease in the integrated indicator, which has a medium level is 0.58 . 
The special VAT regime for sectoral entrepreneurship in rural areas was the only and effective mechanism of indirect state support. Therefore, due to its suspension, the amount of budget subsidies since 2015 has increased from 20.0 million USD up to 147.9 million USD in 2019 (Order of the Cabinet of Ministers of Ukraine No. 995-p, 2015; Order of the Cabinet of Ministers of Ukraine No. 664-p, 2017). Since 2018, the German-Ukrainian Fund (GUF) programs and agricultural lending programs from the government have been introduced in Ukraine to support lending to sectoral rural enterprises. According to GUF programs, the volume of loans increased by 24.8 million USD, which maximum interest rate was $14.9 \%$.

The number of collected insurance premiums for insurance of risks of sectoral entrepreneurship in rural areas in Ukraine increased in 2010-2019 from 3.03 million USD up to 7.8 million USD (i.e., 2.5 times), but the level of coverage of insurance risks decreased from 50.9\% to $21.5 \%$. The share of insured areas under the relevant state programs in the total insured area in 2019 was $23.7 \%$, which is $8 \%$ higher than in 2017 . At the same time, the amount of insurance payments under state programs for financing sectoral entrepreneurship in rural areas since 2017 has increased almost three times and amounted to 3.8 million USD. This positive trend is related to the conclusion of forwarding exchange contracts of PJSC "State Food and Grain Corporation of Ukraine" and PJSC "Agrarian Fund" with entrepreneurship entities for the purchase of goods on the market for the needs of the state intervention fund for the future (Trusova et al., 2020). Based on the leading financial, economic, budgetary, and social indicators of the impact of state policy on the development of sectoral entrepreneurship in rural areas of Ukraine, we forecast the average annual absolute growth of financial capacity of rural entrepreneurship entities in 2020 and 2021 (Figure 2).

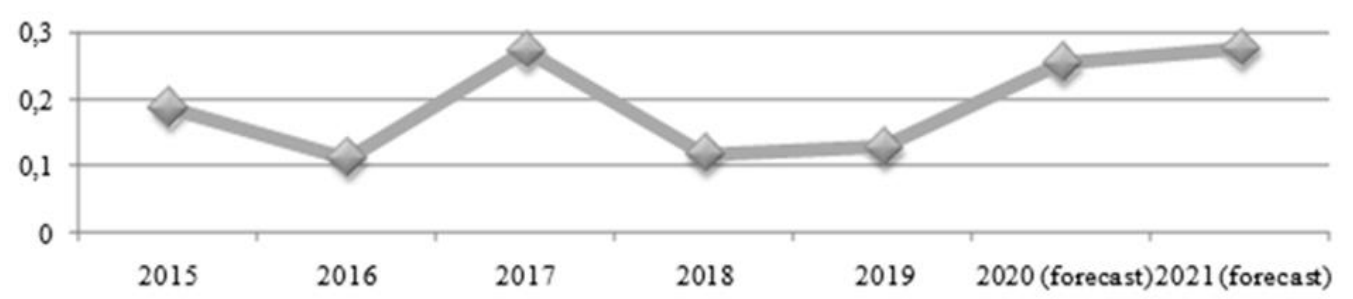

Figure 2. Dynamics (forecast) of the integrated indicator of financial capacity of entrepreneurship entities of rural areas of Ukraine

Source: Authors.

The increase in local budget revenues by almost 5.6 times (from 5.7 billion USD in 2010 to 32.4 billion USD in 2019) allowed local governments to provide targeted distribution of financial resources to develop infrastructure, housing and communal services, health care, education, sports, and culture. Excluding inter-budget transfers for 2019, the revenue side of local budgets of Ukraine received 11.3 billion USD, and, compared to 2015, its size increased by 5.1 billion USD. The share of local budgets (with transfers) in the structure of the Consolidated Budget of Ukraine for 2014-2019 increases from $45.0 \%$ to $56.2 \%$; the share of local taxes and fees in local budgets' revenues increased from 0.7 to $34.8 \%$; the share of own revenues of local budgets (General Fund) in the country's GDP from 5.1\% to 7,8\% (Trusova et al., 2019; Order of the Cabinet of Ministers of Ukraine No. 995-p, 2015).

Given the rapid development of rural areas in Ukraine, we propose a cognitive model that determines the hypothetical ability of a multifactorial system of the institutional environment to influence the level of financial capacity of sectoral entrepreneurship, taking into account the tax burden and targeted financial resources for production, processing, and storage of agricultural products, as well as to update the technological process. The following factors of the level of ensuring the financial capacity of the entities of the sectoral entrepreneurship are offered: Fs1 is provision of financial resources; Fs 2 is the volume of production, processing, and storage of agricultural products in rural areas; Fs 3 is the number of accumulated profits by entrepreneurship entities; Fs 4 is the amount of own financial potential of the entities of sectoral entrepreneurship; Fs5 is the level of 
entrepreneurial activity; Fs6 is tax burden on entrepreneurship entities in rural areas; Fs7 is state support for sectoral entrepreneurship in rural areas; Fs8 is the amount of foreign investment in the development of industry entrepreneurship; Fs9 is the export potential of rural areas; Fs10 is the amount of targeted involvement of financial resources of local budgets in the process of diversification of the rural economy; Fs11 is financing of a technical and technological process; Fs12 is the volume of investment loans for rural areas development. To determine the positive and negative multifactorial impact of the institutional environment on the level of ensuring the financial capacity of entrepreneurship entities, we have used a matrix of acceleration and deceleration, a set of stimulating and disincentive interactions. The most significant factors of interaction within the acceleration and deceleration matrix are Fs1, Fs2, Fs3, Fs7, Fs8, Fs9, Fs11.

The result of sensitivity analysis allowed identification groups of factors in the following areas: target factors of change or stabilization, to manage the financial capacity of entrepreneurship entities: Fs1, Fs2, Fs9; factors of control levers (control factors) that potentially affect the level of ensuring the financial capacity of entities: Fs3, Fs7, Fs8, Fs11; factors-indicators of the development of the process of ensuring the financial capacity of entities: Fs4, Fs5, Fs6, Fs10, Fs12. Thus, from the set of the multifactor institutional environment, the most active levers that positively affect the level of financial capacity of sectoral entrepreneurship are government support, foreign investment, accumulated profits, and financing of the technological process of production, processing, and storage of agricultural products, aimed at the development of sectoral entrepreneurship.

\section{Conclusions}

1. Thus, the implementation of the results of state policy on the indicators of financial, economic, budgetary, and social development of rural areas allowed determining the priority of the target direction of the financial resources involved in the field of sectoral entrepreneurship. Substantiated and expanded comprehensive assessment of the impact of the institutional environment of state policy on the financial capabilities of entrepreneurship entities allowed taking into account the system of tax and social burden, thus determining scenarios of financial support for the technological process of production, processing, and storage of agricultural products.

2. We believe that the strategic vector of state policy for the development of sectoral entrepreneurship in rural areas should provide: 1) stimulating entrepreneurial activity, expanding the export potential of agricultural sectors, increasing the production of labour-intensive products, which, in turn, will increase employment and income of the rural population; 2) state guarantees for the rational use of natural resources, food safety, environmental safety; 3) social guarantees for the rural population based on state programs for rural development.

3. The formed strategic and tactical goals of state support of sectoral entrepreneurship should be formed based on the priority of development, namely, the necessity of qualitative updating of material and technical base and creation of new logistic infrastructure of storage and realization of agricultural products of markets expansion. Moreover, ensuring the quality of implementation of these measures is due to the formation of an effective financial support system for entrepreneurial activities in rural areas aimed at improving the access of industrial producers to financial resources in the financial market.

\section{References}

1. Budai, O.V. 2015. "Concepts and signs of state support of agricultural producers in Ukraine”. Law and Society, 5(3): 92-96.

2. Chernikov, D. 2013. Modernization of the system of state support of business entities in Ukraine. Kyiv: National Institute of Strategic Research.

3. Cullen, P., Ryan, M., O’Donoghue, C., Hynes, S., Uallacháin, D.Ó. and Sheridan, H. 2020. "Impact of farmer selfidentity and attitudes on participation in agri-environment schemes". Land Use Policy, 95: article number 104660.

4. Deller, S. and Whitacre, B. 2019. "Broadband's relationship to rural housing values". Papers in Regional Science, 98(5): 2135-2156. 
5. Graskemper, V., Yu, X. and Feil, J.-H. 2021. "Farmer typology and implications for policy design - An unsupervised machine learning approach”. Land Use Policy, 103: article number 105328.

6. Kyrylenko, O. and Tulai, O. 2017. Formation of the financial mechanism of sustainable development of Ukraine. Ternopil: Ternopil National Economic University.

7. Law of Ukraine No. 1877-IV "On state support of agriculture of Ukraine", on June $24,2004$. https://zakon.rada.gov.ua/laws/show/1877-15\#Text [20-12-02].

8. Law of Ukraine No. 2629-VIII "On the state budget of Ukraine for 2019", on November $23,2018$. https://zakon.rada.gov.ua/laws/show/2629-19 [20-12-02].

9. Malik, M.Y. 2012. Socio-economic principles of rural development: economy, entrepreneurship and management. Kyiv: National Scientific Centre "Institute of Agrarian Economics".

10. Oliinyk, O.V. 2013. "Criteria of state support of agricultural enterprises". Economics of agro-industrial complex, 2 : 49-53.

11. Order of the Cabinet of Ministers of Ukraine No. 664-p "About approval of the Concept of development of farms and agricultural cooperation for 2018-2020”, on September 13, 2017. https://zakon.rada.gov.ua/laws/show/6642017-\%D1\%80\#Text [20-12-02].

12. Order of the Cabinet of Ministers of Ukraine No. 995-p "About approval of the Concept of development of rural territories", on September 23, 2015. http://zakon3.rada.gov.ua/laws/show/995-2015-\%d1\%80 [20-12-02].

13. Schmit, T.M. and Severson, R.M. 2021. "Exploring the feasibility of rural broadband cooperatives in the United States: The new New Deal?" Telecommunications Policy, 45(4): article number 102114.

14. Trusova, N.V., Kohut, I.A., Osypenko, S.A., Radchenko, N.G. and Rubtsova, N.N. 2019. "Implementation of the results of fiscal decentralization of Ukraine and the countries of the European Union". Journal of Advanced Research in Law and Economics, 6(44): 1649-1663.

15. Trusova, N.V., Tanklevska, N.S., Synchak, V.P., Prystemskyi, O.S. and Tereshchenko, M.A. 2020. "State Support of Agro-Insurance of Agricultural Risks in the Market of Goods Derivatives of Ukraine". Industrial Engineering and Management Systems, 19(1): 93-102

16. Trusova, N.V., Ternovskyi, V.O. and Tereshchenko, M.A. 2018. Financial reorganization and bankruptcy of enterprises. Melitopol: Publishing House of the Melitopol City Printing House.

17. Zhuk, V.M. 2011. "Theoretical and methodological principles of accounting and control of rural development support”. Economic Sciences - Series “Accounting and Finance”, 8(29): 142-151.

Iryna V. Forkun, Oleksandr S. Prystemskyi, Olha S. Chernenko, Iryna A. Chkan, Inna Ye. Yakusheva

\section{Valstybès paramos institucionalizavimas ir kaimo vietovių sektorinio verslumo plètra}

\section{Anotacija}

Straipsnyje pristatomas sektorinio verslumo rẻmimo rezultatų igyvendinimas kaimo vietovèse, kaip daugiafunkcinis ir daugiakanalis finansinių išteklių formavimo, pritraukimo ir panaudojimo procesas, numatytas valstybès politikos institucinės aplinkos taisyklèse. Pateikiamas metodinis požiūris į integruotą valstybès finansinių išteklių tikslinès krypties rodiklių ir jų poveikio sektorinio verslumo plètrai kaimo vietovèse vertinimą. Irodyta, kad konkretūs kriterijai, pagal kuriuos nustatomi mokesčių pajamų konsolidavimo ị vietos kaimo biudžetus scenarijai, yra diskrecijos, kompensacijų ir kompromisų sumažinimas, biudžeto pakankamumas, papildomumas, taip pat mokesčių sistemos parametrų ir lankstumo pokyčių seka. kuri leidžia greitai reaguoti i pokyčius institucinejje sektoriaus verslumo paramos valstybejje aplinkoje. Analizuojami valstybès paramos sektorinio verslumo rizikos draudimui rodikliai, vietinių biudžetų sukauptų pajamų apimtys decentralizuotose Ukrainos kaimo vietovèse. Siūlomas pažinimo modelis. Jis nustato hipotetinị valstybès politikos institucinès aplinkos daugiafaktorinès sistemos gebèjimą paveikti sektorinių įmonių finansinio pajègumo lygị, atsižvelgiant ị mokesčių naštą ir tikslinị valstybès finansinių išteklių naudojimą žemès ūkio produktų gamybai, perdirbimui ir laikymui bei atnaujinimo technologini procesą.

Iryna V. Forkun - PhD in Technical Sciences, Associate Professor at the Department of Finance, Banking and Insurance, Khmelnytskyi National University, Khmelnytsky, Ukraine.

E-mail: forkun76@ nuos.pro 
Oleksandr S. Prystemskyi - Full Doctor in Economics, Associate Professor at the Department of Accounting and Taxation, Kherson State Agricultural University, Kherson, Ukraine.

E-mail: ol-prystemskyi@ tanu.pro

Olha S. Chernenko - PhD in Economics, Junior Researcher at the Department of Financial and Credit and Tax Policy, National Scientific Centre "Institute of Agrarian Economics", Kyiv, Ukraine.

E-mail: chernenko62@ust-hk.com.cn

Iryna A. Chkan - PhD in Economics, Associate Professor at the Department of Finance, Banking and Insurance, Dmytro Motornyi Tavria State Agrotechnological University, Melitopol, Ukraine.

E-mail: ira.chkan@uohk.com.cn

Inna Ye. Yakusheva - PhD in Economics, Associate Professor at the Department of Finance, Banking and Insurance, Dmytro Motornyi Tavria State Agrotechnological University, Melitopol, Ukraine.

E-mail: prof.yakusheva@uohk.com.cn

Iryna V. Forkun - technikos mokslų daktarè, docentè, Finansų, bankų ir draudimo katedra, Necionalinis Khmelnitski universitetas, Khmelnitski, Ukraina.

E-mail: forkun76@nuos.pro

Oleksandr S. Prystemskyi - ekonomikos mokslų daktaras, docentas, Mokesčių ir buhalterijos katedra, Valstybinis Kherson Žemės ūkio universitetas, Kherson, Ukraina.

E-mail: ol-prystemskyi@ tanu.pro

Olha S. Chernenko - ekonomikos mokslų daktarè, jaunoji tyrëja, Finansų, kresitų ir mokesčių politikos katedra, Nacionalinis mokslų centras "Žemès ūkio ekonomikos institutas", Kijevas, Ukraina.

E-mail: chernenko62@ust-hk.com.cn

Iryna A. Chkan - ekonomikos mokslų daktarè, docentè, Finansų, bankų ir draudimo katedra, Valstybinis Dmytro Motorni Tavria Žemès ūkio technologijų universitetas, Melitopolis, Ukraina. E-mail: ira.chkan@uohk.com.cn

Inna Ye. Yakusheva - ekonomikos mokslų daktarè, docentė, Finansų, bankų ir draudimo katedra, Valstybinis Dmytro Motorni Tavria Žemès ūkio technologijų universitetas, Melitopolis, Ukraina. E-mail: prof.yakusheva@uohk.com.cn 